\title{
The effects of environmental integrity on the diversity of mayflies, Leptophlebiidae (Ephemeroptera), in tropical streams of the Brazilian Cerrado
}

\author{
Leandro S. Brasil ${ }^{1 *}$, Leandro Juen ${ }^{2}$ and Helena S. R. Cabette ${ }^{1}$ \\ 1 Programa de Pós Graduação em Ecologia e Conservação - Universidade do Estado de Mato Grosso (UNEMAT) - Br 158, Km 655 \\ - Cep. 78690-000 Caixa postal 08, Nova Xavantina, MT, USA \\ ${ }^{2}$ Laboratório de Ecologia e Conservação, Instituto de Ciências Biológicas - Universidade Federal do Pará (UFPA) - Rua Augusto \\ Correia, no 1, Bairro Guamá, Cep 66075-110, Belém, PA, USA
}

Received 9 July 2014; Accepted 9 October 2014

\begin{abstract}
Aquatic insects are widely distributed, and are especially diverse and abundant in tropical streams, where they play an important role in the food chain due to their diversity of feeding strategies, and the potential for the transfer of energy between aquatic and terrestrial environments. The intimate relationship found between these insects and environmental variables means that they are often used as bioindicatorss in environmental studies. We tested the hypothesis that the loss of environmental integrity in tropical streams will lead to a loss of species and a decline in the abundance of mayflies (Leptophlebiidae), in addition to a change in species composition, and the dynamics of population. Collect immature leptophlebiids in 18 streams representing different degrees of conservation, in the Brazilian Cerrado. The environmental integrity of the sites was assessed using a Habitat Integrity Index (HII), which generates values of zero (degraded) to one (preserved), based on soil use, the extension and conservation of riparian forest, as well as morphological features of the stream. A total of 4945 immature leptophlebiids were collected and identified as belonging to 16 species or morphospecies. On an average, a reduction of 0.1 in the value of the HII led to the loss of five specimens and one species. The composition of the communities varied systematically along the environmental gradient, with more sensitive species being found only when the index was above a threshold of 0.6 . The importance of the riparian vegetation for the aquatic biota, especially its role in the mitigation of impacts from the surrounding matrix, supports the universal conservation of this type of habitat.
\end{abstract}

Key words: Aquatic insects / anthropogenic impact / conservation / riparian forest / Terpides sooretame

\section{Introduction}

As relatively heterogeneous environments provide a wider range of potential habitats than more homogeneous ones (Warfe et al., 2008), they tend to favor the establishment of richer biological communities, especially in aquatic environments (Tate and Heiny, 1995; Wahl et al., 2013). In general, the loss of environmental quality tends to make habitats more homogeneous, which may have consequences such as the loss of species richness, the modification of species composition, and shifts in abundance patterns (Castello, 2008; Axelsson et al., 2011; Dolný et al., 2012; Carvalho et al., 2013; Ligeiro et al., 2013; Suga and Tanaka, 2013; Wahl et al., 2013). Ultimately, this process may alter the distribution of the

\footnotetext{
*Corresponding author: brasil_biologia@hotmail.com
}

more sensitive species (Souza et al., 2011; Monteiro Júnior et al., 2013).

Under normal conditions, most stream-dwelling species are able to tolerate natural modifications in the physical and chemical environment, reflecting the evolutionary history of these organisms (Karr, 1999). By contrast, anthropogenic impacts - which generally involve modifications of hydrological conditions and feeding resources tend to be more intense and rapid, and generally have negative consequences for aquatic communities (Karr, 1981).

The loss of species tends to be related to changes in the use of the soil, the extension and quality of riparian habitats, and the stream conditions (Nessimian et al., 2008). These changes may alter the balance of nutrients, sediments, debris, and substrates, which is essential to the trophic structure of a community (Allan, 2004; 
Yoshimura, 2012). In particular, a reduction in riparian forest cover, generally results in a decrease in the abundance of shredders - due to a decline in the supply of dead leaves and an increase in sunlight penetration - while the abundance of scrapers expands (Brasil et al., 2013).

Environmental heterogeneity is a major factor determining the biodiversity of aquatic systems (Popielarz and Neal, 2007), by enabling the more ample partitioning of niches (Holzman et al., 2011; Heino, 2013). Impacted environments tend to become more homogeneous, resulting in a decline in diversity due to the prevalence of more generalist species over specialist ones (Popielarz and Neal, 2007).

The Leptophlebiidae is one of the predominant and most diverse groups of organisms found in Neotropical streams (Savage, 1987; Domínguez et al., 2006). These mayflies tend to be abundant and widely distributed, and are found in rhithral and potamal lotic habitats, as well as semi-lotic environments, such as rhithral impoundments or flooded forests (Da Silva et al., 2010). These organisms are also crucial to nutrient cycling in aquatic ecosystems due to their functional roles as scrapers, filterers and shredders of organic matter (Baptista et al., 2006; Bello and Cabrera, 2001; Shimano et al., 2012; Brasil et al., 2013).

Leptophlebiids are the most common ephemeropterans in the Eastern Mato Grosso, with the second highest species richness, and a wide range of feeding adaptations and habitat preferences, from headwater brooks to main rivers. They are normally found in well-preserved or only slightly impacted habitats (Shimano et al., 2010) and are useful indicators of environmental quality (Brasil et al., 2013).

While environmental awareness is growing worldwide, in many cases, the understanding of the planet's biodiversity remains incipient, and estimates of the total number of extant species vary by up to two orders of magnitude (Whittaker et al., 2005). In the context of ongoing anthropogenic changes to the environment, in fact, many species may become extinct before being made known to Science (Primack and Rodrigues, 2001). Aquatic insects are typical in this respect, at both regional and global scales (Contador et al., 2012). In the specific case of the Ephemoptera, most Brazilian studies have focused on the fauna in the south of the country, representing a Wallacean shortfall, and typically at a low taxonomic resolution (Linnaean shortfall). Conservation-oriented studies or community-level analyses related to environmental variables are rarer still (Shimano et al., 2013a, 2013b), and represent a major gap in the understanding of the relationship between environmental factors and diversity.

Given the potential role of aquatic insects as bioindicators of the anthropogenic disturbance of bodies of water (Silva et al., 2010; Corbi et al., 2013; Monteiro et al., 2013), the environmental integrity of streams in the Brazilian Cerrado savanna was analyzed and related systematically to the structure of the local populations and communities of mayflies (Leptophlebiidae). Two hypotheses were tested. The first was that a loss of environmental quality would result in a decrease in species richness and a decline in the abundance of individuals, based on the assumption that highly impacted environments will become more homogeneous. The second hypothesis is that the resulting decrease in diversity and resources will cause changes in species composition and population dynamics.

\section{Methods}

Eighteen locations (sites) were sampled in first- to third-order steams (based on Strahler's 1957 classification). They were $3.4 \pm 1.8 \mathrm{~m}$ wide, on average ( \pm standard deviation) and had a mean depth of $0.5 \pm 0.2 \mathrm{~m}$. The streams were located in three hydrographic sub-basins in the Brazilian Cerrado savanna - Corrente, Pindaíba and Suiá-Missu - all in the east of Mato Grosso State (Fig. 1). The Suiá-Missu River is a tributary of the Xingu River (a major tributary of the Amazon River), and its basin includes parts of the municipalities of Querência, Ribeirão Cascalheira and Canarana, and encompasses areas of both Cerrado and the transition zone between the Cerrado savanna and the Amazon rainforest. The Corrente and Pindaíba rivers are tributaries of the Mortes River, located within the Cerrado proper, where their basins includes parts of the municipalities of Barra do Garça, Araguaiana, Cocalinho and Nova Xavantina.

The region's climate is classified as Aw (Peel et al., 2007), that is, seasonal tropical, with two well-defined seasons, a dry season between May and October, and a rainy season between November and April. During the respective study periods, annual rainfall was $1650 \mathrm{~mm}$ in the Suiá-Missu region, with a mean monthly temperature of $25.2^{\circ} \mathrm{C}(2007 / 2008)$, while annual rainfall was $1315 \mathrm{~mm}$ in 2005 in the region of Pindaíba and Corrente, with a mean monthly temperature of $26.4^{\circ} \mathrm{C}$ (INMET, 2013).

The study sites varied systematically in relation to the use of the soil in the matrix surrounding the riparian zone. Six sites $(33 \%)$ present a matrix of continuous savanna woodland, four $(22 \%)$ are surrounded by secondary forest, six (33\%) by cattle pasture (Brachiarea spp.) and two (12\%) by short-cycle crops (soy, corn or pearl millet).

\section{Collection of biological material}

Specimens were collected during three periods at all sites, representing the early rainy, rainy and dry seasons. In the Suiá-Missu basin, fieldwork was conducted in September, 2007 (early rainy season), December, 2007 (rainy season) and May, 2008 (dry season), while in the Pindaiba and Corrente basins, specimens were collected in January (rainy season), July (dry season), and October (early rainy season), 2005. The collection of samples during the different seasons was essential to minimize the potential effects of seasonal factors - which are especially pronounced in the Cerrado biome. 


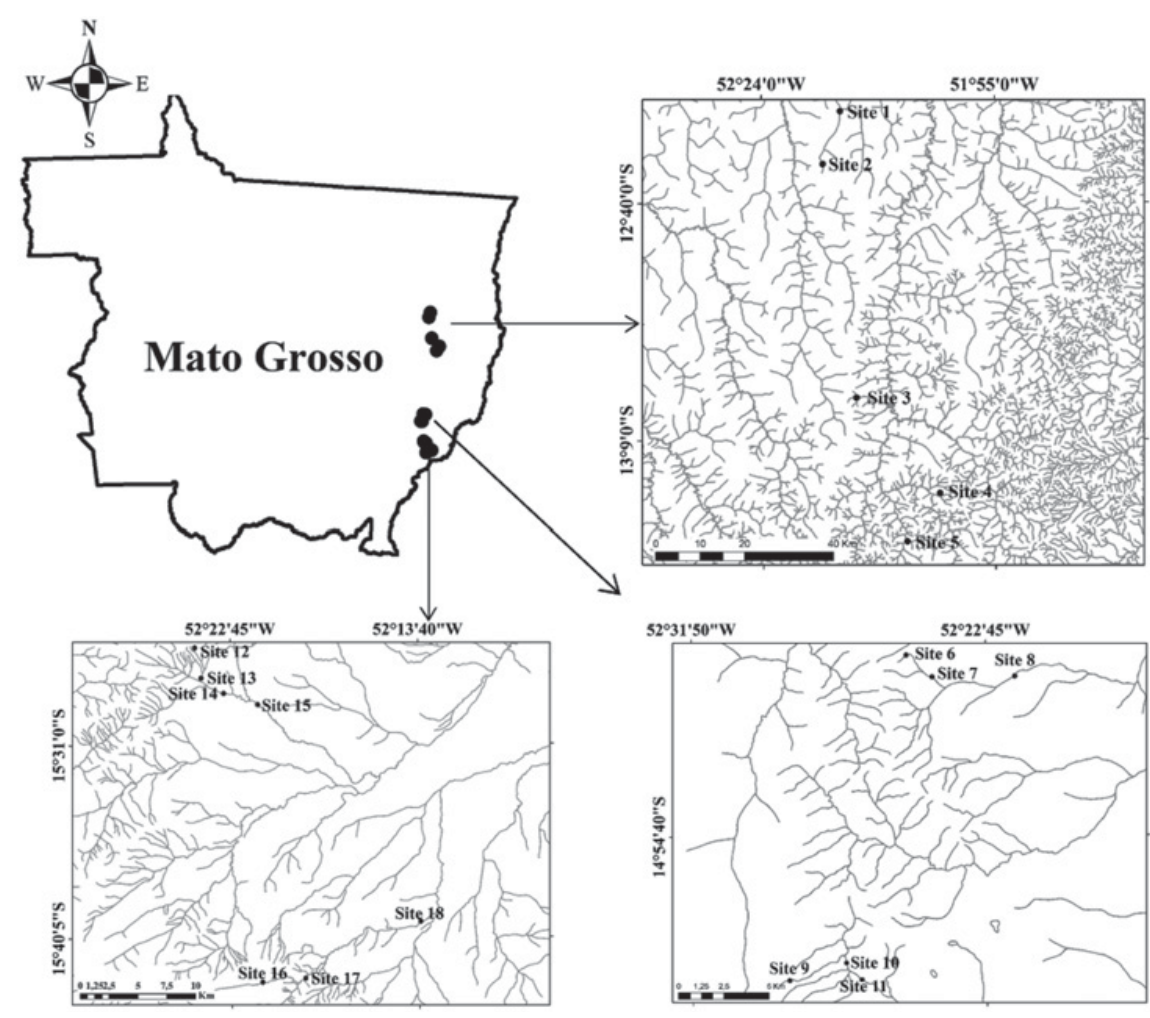

Fig. 1. Distribution of the 18 study sites in the Suiá-Missu (1-5), Pindaíba (6-11) and Corrente (12-18) basins representing tropical lotic systems in Mato Grosso, Brazil.

A $100 \mathrm{~m}$ linear transect was demarcated at each site, on the right bank (upstream $>$ downstream) the stream. These transects were divided into 20 segments of $5 \mathrm{~m}$. Three substrate samples were collected in each segment, from the center to the edge, using an $18 \mathrm{~cm}$ diameter sieve with a 250 um mesh (Cabette et al., 2010). The organic material was separated in the field and stored in $85 \%$ alcohol. The leptophlebiids were identified using the identification keys of Domínguez et al. (2006), Salles (2006) and Dias et al. (2007). The voucher specimens were deposited in the "James Alexander Ratter" zoobotanical collection at the Nova Xavantina campus of Mato Grosso State University (UNEMAT) in Nova Xavatina, Mato Grosso, Brazil.

\section{Collection of environmental data}

The degree of conservation of each stream was evaluated using the protocol of Nessimian et al. (2008, 2013). This protocol is composed of 12 variables (see attachment) that assess the use of the soil, the presence and conservation of the riparian vegetation, as well as stream morphology and other features. The compilation of the scores for the different variables provides a Habitat Integrity Index (HII) for each site. Each variable is scored on the basis of four to six alternatives, ordered from the lowest to the highest degree of perceived integrity. The final index varies from zero to one, with the highest scores referring to the most intact environments. The index has been used in a number of studies of environmental impact, and has produced good results for the analysis of the communities of a number of taxonomic groups of aquatic insects across different regions (e.g., Dias-Silva et al., 2010; Silva et al., 2010; Souza et al., 2011; Pereira et al., 2012; Silva-Pinto et al., 2012; Brasil et al., 2013; Carvalho et al., 2013).

\section{Data analysis}

A principal components analysis (PCA) was used to order the environmental variables and visualize the arrangement of the study sites within the observed gradient. The axes were selected randomly using the broken-stick model (Jackson, 1993). The relationship among the 12 environmental variables determined the HII and PCA axes (loading). A correlation threshold of 0.7 was considered relevant for discussion in the present study (Peres-Neto et al., 2003).

Each study site represented a single sampling unit for the analysis of species richness and abundance, based on the 20 samples collected within each transect. Estimates of species richness were used as the dependent variables in order to test the hypothesis that the loss of environmental integrity would lead to a decrease in the number of species. The HII scores for each stream were used as the independent variables (Zar, 2010). For this regression, species richness was estimated using a first-order nonparametric Jackknife analysis (Colwell and Coddington, 
1994) run in EstimateS Win, version 7.5 (Colwell, 2004). This procedure is recommended for conservation-oriented studies due to its focus on rare species (De Marco and Siqueira, 2009).

A principal coordinates analysis ( $\mathrm{PCoA}$ ) was used to order the communities based on the log-transformed $[\log (x+1)]$ abundance data (Legendre and Legendre, 2012) and the Bray-Curtis dissimilarity index (Clarke, 1993). The second hypothesis, that the loss of environmental quality would cause changes in the species composition as well as the distribution of populations along the environmental gradient, was first tested using Pearson's coefficient of correlation (Zar, 2010). For this, the PCoA scores for the significant axes ( 1 and 2$)$ were used as response variables, and their HII scores as their predictors. A gradient analysis, based on Landeiro et al. (2010) was applied for the assessment of the distribution of the populations along the environmental gradient.

The proportional contribution of each species to the gradient was evaluated using regression models, in which the occurrence of a species at a given site was the response variable, and the local HII was the predictor variable. Only those species found at five or more sites were included in this analysis to ensure the statistical assumptions of the procedure.

\section{Results}

\section{Habitat quality}

The HII scores reflected an environmental gradient which varied from 0.39 to 0.96 . More than half $(54 \%)$ of the variation was explained by the first two PCA axes. Of the habitat variables analyzed in the present study, the width of riparian forest was related negatively to the first axis, which groups the better preserved sites. This indicates that the width of the riparian forest is the parameter that has the strongest influence on the environmental integrity of a stream.

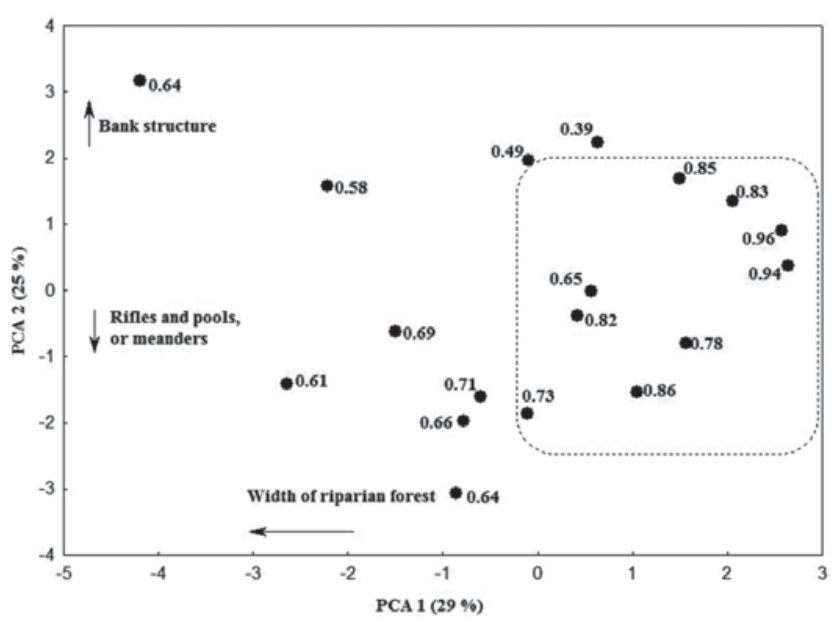

Fig. 2. Analysis of the habitat features of the 18 tropical lotic study sites in Mato Grosso, Brazil, ordered by their HII scores. The groups of preserved sites are outlined by a dotted line.

On the second axis, the bank structure, including erosion and excavation, was positively related to the group of three sites that were the most impacted. Riffles and pools, or meanders, which reflect the heterogeneity of the stream environment were also related negatively with this group (Fig. 2, Table 1). Overall, the analysis confirmed that streams with a more ample riparian zone tend to be more intact, while those that have suffered more intense impacts tend to be characterized by a more homogenized channel.

\section{Effects of the environmental gradient on leptophlebiids}

A total of 4945 immature leptophlebiids were collected during the present study (Table 2), of which the most abundant were those of the genus Miroculis spp. (1785 specimens or $36.1 \%$ of the total), followed by Farrodes sp. (1190 specimens, 24.1\%) and Terpides sooretamae

Table 1. Correlations between the components of the HII and the first and second PCA axes, along the anthropogenic gradient of tropical lotic systems in Mato Grosso, Brazil.

\begin{tabular}{lrr}
\hline & & \multicolumn{1}{c}{ Loadings } \\
\cline { 2 - 3 } Environmental features & \multicolumn{1}{c}{ Axis 1 } & -0.581 \\
\hline Land use pattern beyond the riparian zone & -0.518 & $-\mathbf{0 . 8 8 5}$ \\
Width of riparian forest & -0.682 & 0.005 \\
Completeness of riparian forest & -0.622 & 0.436 \\
Vegetation of riparian zone within 10 m of channel & -0.687 & 0.442 \\
Retention devices & -0.099 & -0.536 \\
Channel sediments & -0.376 & -0.556 \\
Bank structure & -0.312 & $\mathbf{0 . 7 7 3}$ \\
Bank undercutting & -0.493 & 0.583 \\
Stream bottom & -0.374 & -0.532 \\
Riffles and pools, or meanders & -0.371 & $-\mathbf{0 . 7 6 3}$ \\
Aquatic vegetation & -0.571 & 0.068 \\
Debris & $\mathbf{3 . 4 7 0}$ & 0.289 \\
Self-values & $\mathbf{3 . 1 0 3}$ & $\mathbf{2 . 9 6 8}$ \\
Broken-stick & & $\mathbf{2 . 1 0 3}$ \\
\hline
\end{tabular}


Table 2. Abundance of species/morphospecies of immature leptophlebiids in lotic tropical systems at 18 sites in Mato Grosso (Brazil).

\begin{tabular}{ll}
\hline Species/morphospecies & Abundance \\
\hline Askola sp. & 53 \\
Farrodes sp. & 1190 \\
Fittkaulus cururuensis (Savage, 1986) & 164 \\
Simothraulopsis sp. 1 & 83 \\
Hagenulopsis sp. & 190 \\
Hydrosmilodon gilliesae (Thomas and Péru, 2004) & 11 \\
Microphlebia sp. & 5 \\
Miroculis sp. & 1785 \\
Paramaka convexa (Spieth, 1943) & 24 \\
Simothraulopsis sp. 2 & 27 \\
Tikuna bilineata (Needham and Murphy, 1924) & 1 \\
Terpides sooretamae (Boldrini and Salles, 2009) & 1078 \\
Thraulodes sp. & 27 \\
Traverella sp. & 15 \\
Ulmeritoides sp. 1 & 122 \\
Ulmeritoides sp. 2 & 170 \\
Total & 4945
\end{tabular}

Boldrini and Salles, 2009, represented by 1078 specimens (21.8\% of the total). The rarest species were Hydrosmilodon gilliesae Thomas and Péru 2004, with 11 specimens $(<1 \%)$, Microphlebia sp., with five $(<1 \%)$, and Tikuna bilineata (Needham and Murphy 1924), with just one ( $<0.5 \%)$.

Environmental integrity had a positive effect on species richness $\left(r^{2}=0.284 ; P=0.022\right)$ and abundance, $r^{2}=0.413$; $P=0.004$ (Fig. 3(A) and (B)). On average, a 0.1 increase in the HII score resulted in the addition of one species and five specimens.

Variation in the composition of the communities along the environmental gradient was evident from the first PCoA axis, with an explanatory value of $44 \%$. The communities from well-preserved sites are well grouped along this axis, whereas impacted sites are more dispersed (Fig. 4). Overall, the analysis indicated that the main factor contributing to the distribution of the communities along the first and second PCoA axes was the HII (Fig. 5). As a result, a strong correlation $(r=0.783 ; P<0.0001)$ was found with the main axis, but not the secondary axis $\left(r^{2}=0.001 ; P=0.878\right)$.

The distribution of populations along the gradient reflected major differences among them (Fig. 6). The populations of three taxa $-T$. sooretamae, Farrodes sp. and Simothraulopsis sp.1 was only found in streams with HII. All three species presented a positive relationship with integrity in the logistic regression (Fig. 7(A)-(C)), although other species were not related systematically $(P>0.05)$ to the gradient.

\section{Discussion}

\section{Habitat quality}

The quantification of environmental disturbance is a major challenge for the management of water resources, given that the establishment of regulatory criteria depends
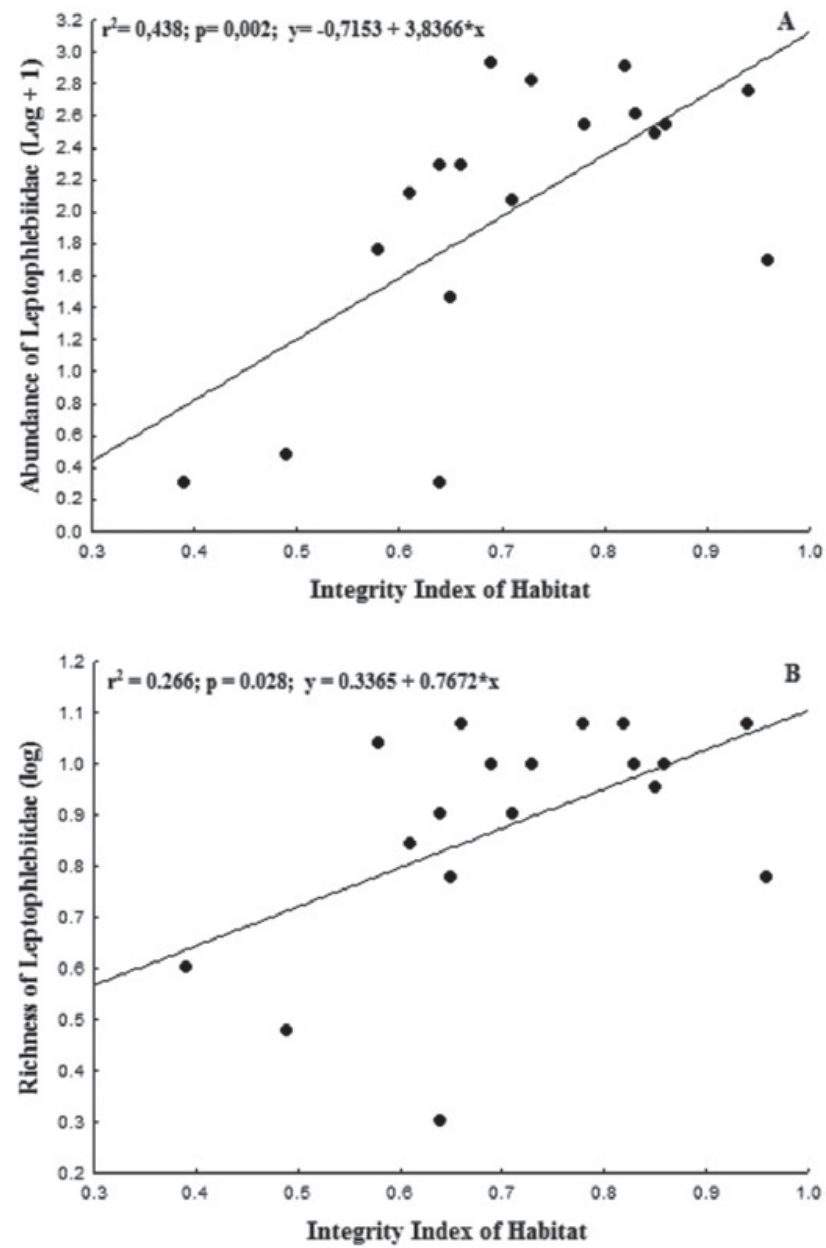

Fig. 3. Relationship between the HII scores and the abundance (A) and estimated richness (B) of leptophlebiid species in the tropical lotic systems studied in Mato Grosso, Brazil.

on the identification of standardized reference conditions (Brenden et al., 2008). The results of the present study indicated a significant gradient of anthropogenic impact among sites. This supports the conclusion that the width of the riparian forest is the principal determinant of the variation in environmental integrity.

Impacts on the riparian forest result in modifications in the physical (turbidity and conductivity) and chemical (nitrate, potassium, calcium and magnesium concentrations) characteristics of the water. In areas affected by intense agricultural activities, where contamination from the runoff of nitrogenous fertilizers is common, the riparian vegetation plays an important role as a buffer zone for the mediation of the effects of the input of sediments, nutrients and contaminants from the surrounding matrix (Klapproth and Johnson, 2000; Dosskey et al., 2010; Wahl et al., 2013).

\section{Effects of the environmental gradient}

The loss of integrity was associated with changes in the morphology of the stream channel, such as the 


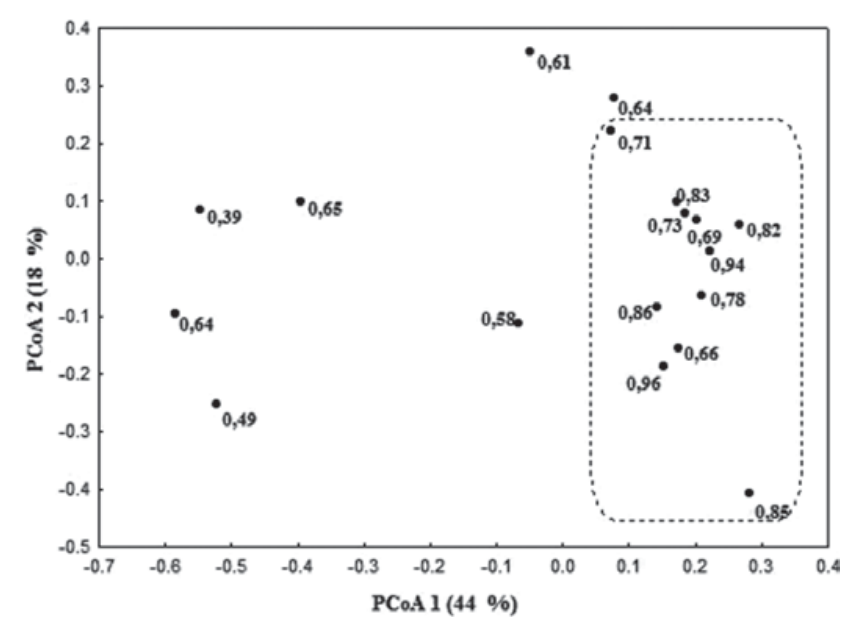

Fig. 4. PCA of the composition of leptophlebiid communities at the 18 tropical lotic sites analyzed in Mato Grosso, Brazil. The groups of preserved sites are outlined by a dotted line.

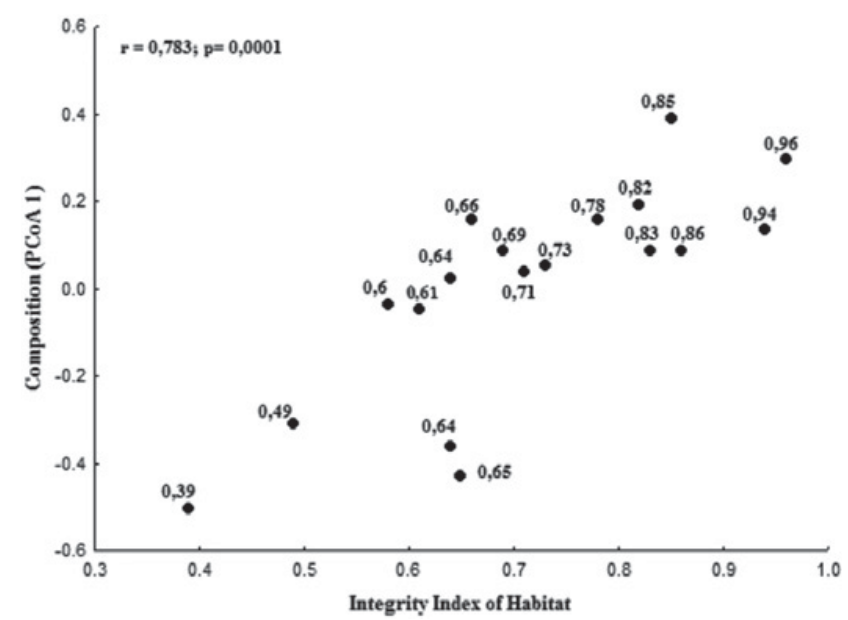

Fig. 5. The correlation of the HII scores with the main ordering axis (PCoA) of community composition along the anthropogenic environmental gradient of tropical lotic systems studied in Mato Grosso, Brazil.

structure of the bank, and the presence of rapids, swamps or other features. This process results from the gradual change in the use of land in the matrix surrounding the riparian vegetation, which ultimately provokes direct impacts on the structure of the streams. In particular, erosion and deposition processes may be accentuated and accelerated (Allan, 2004; Bacellar, 2005).

Integrity was a major factor determining the characteristics of the aquatic communities, given that species richness, abundance and composition varied systematically along the environmental gradient established in the present study. These results confirmed the conclusion that a reduction in environmental integrity results in a loss of species richness and abundance, as well as changes in the composition of the community, and the distribution of species.

The loss of integrity indicated by the HII may be a good predictor of the diversity and abundance of many

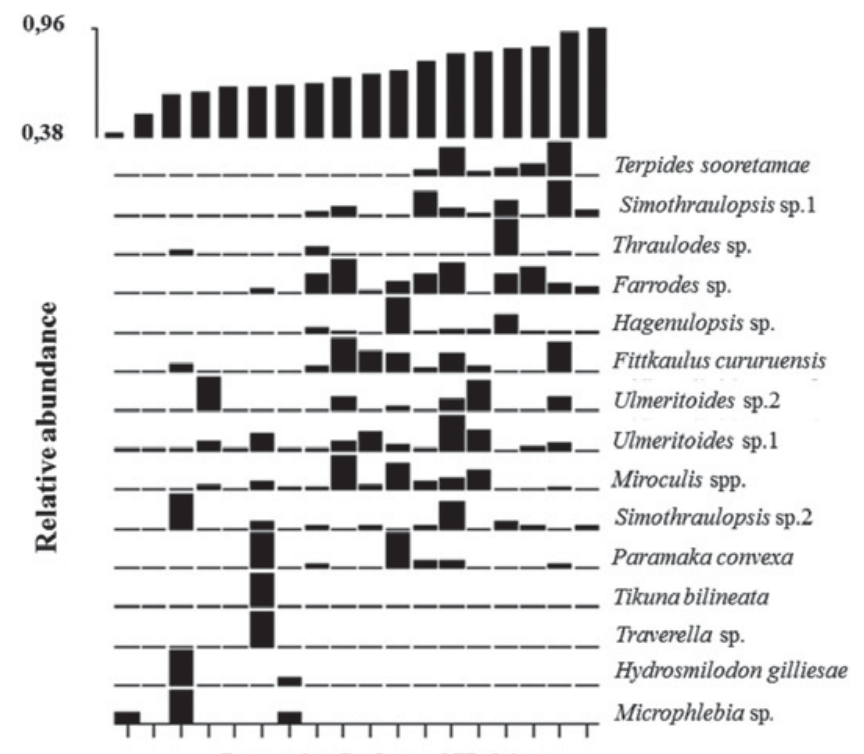

Integrity Index of Habitat

Fig. 6. Distribution of the leptophlebiid populations within the anthropogenic habitat gradient of tropical lotic systems in Mato Grosso, Brazil.

taxonomic groups in aquatic systems, as long as appropriate variables are analyzed. Dias-Silva et al. (2010) found a reduction in the species richness of Gerromorpha (Heteroptera) with decreasing habitat integrity, for example, while Silva-Pinto et al. (2012), detected morphometric asymmetries in odonates. Pereira et al. (2012) recorded alterations in the species composition of an assemblage of Trichoptera, while Carvalho et al. (2013) observed a shift in the species richness of odonates, and Brasil et al. (2013) recorded a reduction in the abundance of shredder leptophlebiids. Leptoblebiids have also been shown to be good indicators in other parts of the world. In Southern China, the occurrence and abundance of these mayflies decreased as water quality declined (Xu et al. 2014), while in India, these insects were absent from sites at which the riparian vegetation had been modified for the establishment of plantations (Selvakumar et al., 2014), while species richness was much lower in Southwestern Australia, were climatic conditions were less favorable (Bunn and Davies, 1990).

The loss of up to $42 \%$ of invertebrate species has been recorded in areas where agricultural activities in the surrounding matrix are intense, and cause contamination of the water with pesticides (Beketov et al., 2013). Different patterns of land use in the matrix surrounding the riparian zone may have a considerable impact on the species richness and composition of aquatic insects, such as ephemeropterans, plecopterans and trichopterans (Nessimian et al., 2008, 2013). Zweig and Rabeni (2001) and Allan (2004) have linked the loss of species richness and abundance with increased siltation, which leads to a decline in biodiversity and, as a consequence, the ecosystem services provided by the species lost due to environmental impacts. 

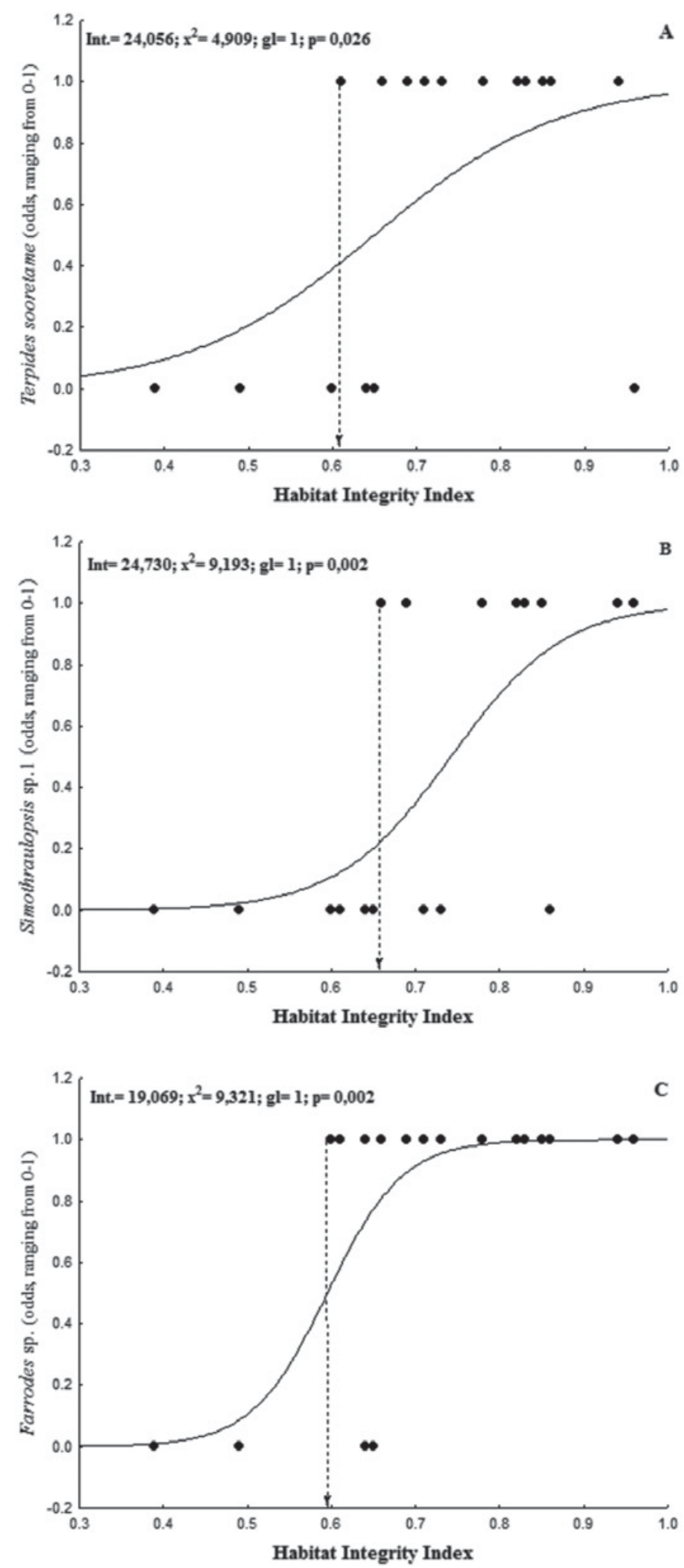

Fig. 7. The occurrence (odds, ranging from 0 to 1) of (A) Terpides sooretame, (B) Simothraulopsis sp.1, and (C) Farrodes sp. at the different study sites in Mato Grosso, Brazil, ranked by their HII scores. The dotted lines indicate the minimum integrity threshold for the occurrence of each species.

Thorp et al.'s (2006, 2008) theory of hierarchical patches establishes that the availability of patches on different scales within the aquatic system predicts the occurrence of species, according to their environmental requirements. The distribution of these patches within the system will determine the composition of local communities. Environmental changes - in particular those related to resource availability (Bispo et al., 2006) and the homogenization of habitats (Ligeiro et al., 2013; Shimano et al., 2013a, 2013b) - will alter the configuration of niches, affecting the demographic capacity of species (Chave, 2004), and changing species richness and abundance within the community resulting from these environmental filters (Buss et al., 2002; Bispo et al., 2006; Dolný et al., 2012; Brasil et al., 2014).

Whenever the resources within a given system become less abundant than average in the region, due to environmental changes, community structure tend to be partially or even totally differentiated from the typical regional pattern of diversity (Silva et al., 2010). This happens because changes in the availability of resources in lotic systems alter the distribution of communities (Vannote et al., 1980; Poole, 2002).

The life history and foraging behavior of leptophlebiid species are the principal determinants of their population dynamics (Scrimgeour, 1991), and the distribution of functional feeding groups is related intimately to factors such as river flow and the availability of resources, e.g., organic matter and periphyton (Bello and Cabrera, 2001). Anthropogenic impacts that modify the availability of such resources are also reflected in changes in community structure.

The identification of the ecological characteristics of populations within each community is essential for the understanding of the variation in species composition along the environmental gradient. In this study, the species that presented the most systematic relationship with wellpreserved habitats was $T$. sooretamae. Unfortunately, no ecological data are available for this recently described species (Salles et al., 2010).

The leptophlebiids of the genus Terpides Demoulin 1966 are strongly related with riparian forests, and are generally found close to the margins of small streams (Domínguez et al., 2006), where they feed on fragments of organic matter (Shimano et al., 2012). Given the ample distribution of the genus, and the abundance of these mayflies at most sites, which facilitates the identification of species, Terpides appears to be a strong candidate for a bio-indicator of preserved environments.

The genus Farrodes Peters 1971 is highly adaptable in ecological terms (Savage, 1987; Baptista et al., 2006; Domínguez et al., 2006). In the present study, Farrodes sp. was related positively with habitat integrity. Simothraulopsis sp. 1 also presented a positive relationship with habitat integrity and contrasted with the other members of the genus in morphology (posterolateral spines in segments 6-9) and ecological traits. This morphospecies differed from Simothraulopsis sp. 2, which did not present any obvious degree of sensitivity to environmental change. These findings indicate that genus-level taxa may not be appropriate for studies that evaluate environmental impacts, and that mayfly species 
(rather than genera) must be used as bio-indicators, in order to avoid the misinterpretation of results.

H. gilliesae Thomas and Péru 2006 and Traverella sp. are members of the filter-collector guild (Cummins, 1973; Polegatto and Froehlich, 2003; Allan and Castillo, 2007), and were only found at the more impacted sites. These species may have been favored by an increase in the deposition of debris, which is typical of impacted stream habitats. The reduction in the width of the riparian forest normally results in an increase in the amount of debris within the stream channel, although the small number of specimens collected in the present study hampers a more conclusive analysis of potential indicator taxa for environmental monitoring (Nessimian et al., 2008).

Overall, the reduction in environmental integrity resulted in major impacts on the leptophlebiid communities. Considering the mean integrity of the sites in the present study $(\mathrm{HII}=0.7)$, the regression indicated a mean loss of 15 specimens and five species per site, altering the composition of the communities along the environmental gradient, given that the majority of populations coincided with the most well-preserved extreme of the gradient.

The width of the riparian forest was the principal factor determining the environmental integrity of the streams investigated in the present study, and the conservation or restoration of this habitat would appear to be essential for the maintenance of the environmental integrity of the streams. Impacts resulted in the loss of both species and abundance, resulting in changes in the composition of leptophlebiid communities along the environmental gradient. In particular, the findings of the present study indicated that Terpides sooretame would be the best indicator species for the bio-monitoring of the environmental quality of lotic systems.

The environmental gradient, based on the HII, was characterized by significant variation in the characteristics of the leptophlebiid fauna. Special attention is recommended for streams located within areas of intense agricultural activity (agribusiness), which suffer profound structural changes, due to the lack of protected areas or adequate environmental monitoring. Riparian vegetation is protected under Brazilian law and one approach to the conservation or recuperation of the integrity of the region's streams would be to enforce the minimum legal cover of riparian vegetation associated with all the region's streams.

Acknowledgements. We thank the undergrads from the Aquatic Entomology Laboratory at Mato Grosso State University for their assistance, Yulie Shimano and Mariana G. Pavan for their help with the identification of taxa, and Frederico F. Salles for help with taxonomy. We are grateful to the Brazilian higher education training program (CAPES) for a graduate stipend, the Brazilian National Council for Scientific and Technological Development, CNPq (grant no. 520268/2005-9), and the Mato Grosso State Research Foundation (grant numbers 098/2004 and 0907/2006) for financial support. Leandro Juen also acknowledges the ongoing support of CNPq through productivity grants (number 303252/2013-8).

\section{References}

Allan J.D., 2004. Landscapes and riverscapes: the influence of land use on stream Ecosystems. Annu. Rev. Ecol. Evol., 35, 257-284.

Allan J.D. and Castillo M.M., 2007. Stream Ecology: Structure e Function of Running Waters, Chapman-Hall, New York, NY.

Axelsson E.P., Hajalten J., Leroy C.J., Whitham T.G., Julkunen-Tiitto R. and Wennstrom A., 2011. Leaf litter from insect-resistant transgenic trees causes changes in aquatic insect community composition. J. Appl. Ecol., 48, 1472-1479.

Bacellar L.A.P., 2005. O papel das florestas no regime hidrológico de bacias Hidrográficas. Geo br, 1, 1-39.

Baptista D.F., Buss D.F., Dias L.G., Nessimian J.L., Da Silva E.R., De Moraes Neto A.H., Carvalho S.N., De-Oliveira M.A. and Andrade L.R., 2006. Functional feeding groups of Brazilian Ephemeroptera nymphs: ultrastructure of mouthparts. Ann. Limnol - Int. J. Lim., 42, 87-96.

Beketov M.A., Kefford B.J., Schäfer R.B. and Liess M., 2013. Pesticides reduce regional biodiversity of stream invertebrates. Proc. Natl. Acad. Sci. USA, 2, 1-5.

Bello L.C.C. and Cabrera I.M., 2001. Alimentación ninfal de Leptophlebiidae (Insecta: Ephemeroptera) en el Caño Paso del Diablo, Venezuela. Rev. Biol. Trop., 49, 999-1003.

Bispo P.C., Oliveira L.G., Bini L.M. and Sousa K.G., 2006. Ephemeroptera, Plecoptera and Trichoptera assemblages from riffles in mountain streams of Central Brazil: environmental factors influencing the distribution and abundance of immatures. Braz. J. Biol., 66, 611-622.

Brasil L.S., Shimano Y., Batista J.D. and Cabette H.S.R., 2013. Effects of environmental factors on community structure of Leptophlebiidae (Insecta: Ephemeroptera) in Cerrado streams, Brazil. Iheringia Sér Zool, 103, 260-265.

Brasil L.S., Juen J., Batista J.D., Pavam M.G. and Cabette H.S.R., 2014. Longitudinal Distribution of the Functional Feeding Groups of Aquatic Insects in Streams of the Brazilian Cerrado Savan. Neotrop. Entomol., 43, 421-428.

Brenden T.O., Wang L. and SU Z., 2008. Quantitative identification of disturbance thresholds in support of aquatic resource management. Environ. Manage., 42, 821-832.

Bunn S.E. and Davies P.M., 1990. Why is the stream fauna of south-western Australia so impoverished? Hydrobiologia, 194, 169-176.

Buss D.F., Baptista F., Silveira M.P., Nessimian J.L. and Dorvill F.M., 2002. Influence of water chemistry and environmental degradation on macroinvertebrate assemblages in a river basin in south-east Brazil. Hydrobiologia, 481, 125-136.

Cabette H.S.R., Giehl N.F., Dias-Silva K., Juen L. and Batista J.D., 2010. Gerromorpha (Insecta: Heteroptera) da Bacia Hidrografica do Rio Suiá-Miçu, MT: riqueza relacionada a qualidade da água e hábitat. In: Santos J.E., Galbiati C. and Moschini L.E. (eds.), Gestão e educação ambiental água, biomonitoramento e cultura, Editorial RiMa, São Carlos, 113-137.

Carvalho F.G., Silva-Pinto N., Oliveira-Júnior J.M.B. and Juen L., 2013. Effects of marginal vegetation removal on Odonata communities. Acta Limnol. Bras., 25, 10-18.

Castello L., 2008. Lateral migration of Arapaima gig's in floodplains of the Amazon. Ecol. Freshw. Fish, 17, 38-46. 
Chave J., 2004. Neutral theory and community ecology. Ecol. Lett., 7, 241-253.

Clarke K.R., 1993. Non-parametric multivariate analyses of changes in community structure. Austr. Ecol., 18, 117-143.

Colwell R.K., 2004. Estimates: Statistical Estimation of Species Richness and Shared Species from Samples, Version 7.5., Available online at: Publishing Physics Web http:// viceroy.eeb.uconn.edu/estimates. Persistent URL http://purl. oclc.org/estimates. Accessed online 26 June 2013.

Colwell R.K. and Coddington J.A., 1994. Estimating terrestrial biodiversity through extrapolation. Phil. Trans. R Soc. B, $345,101-118$.

Contador T.A., Kennedy J.H. and Rozzi R., 2012. The conservation status of southern South American aquatic insects in the literature. Biodivers. Conserv., 21, 2095-2107.

Corbi J.J., Kleineb P. and Trivinho-Strixino S., 2013. Are aquatic insect species sensitive to banana plant cultivation? Ecol. Indic., 25, 156-161.

Cummins K.W., 1973. Tropidc relations of aquatic insects. Ann. Rev. Ent., 18, 183-206.

Da Silva E.R., Nessimian J.L. and Coelho L.B.N., 2010. Leptophlebiidae ocorrentes no Estado do Rio de Janeiro, Brasil: hábitats, meso-hábitats e hábitos das ninfas (Insecta: Ephemeroptera). Biota Neotrop., 10, 87-94.

De Marco P. and Siqueira M.F., 2009. Como determinar a distribuição potencial de espécies sob uma abordagem conservacionista? Megadiversidade, 5, 65-76.

Dias L.G., Molineri C. and Ferreira P.S.F. 2007. Ephemerelloidea (Insecta: Ephemeroptera) do Brasil. Pap Avulsos Zool., 47, 213-244.

Dias-Silva K., Cabette H.S.R., Juen L. and De Marco P. Jr. 2010. The influence of habitat integrity and physicalchemical water variables on the structure of aquatic and semi-aquatic Heteroptera. Rev. Bras. Zool., 27, 918-930.

Dolný A., Harabiš F., Bárta D. and Lhota S., 2012. Aquatic insects indicate terrestrial habitat degradation: changes in taxonomical structure and functional diversity of dragonflies in tropical rainforest of East Kalimantan. Trop. Zool., 25, 37-41.

Domínguez E., Molineri C., Pescador M.L., Hubbard M. and Nieto V., 2006. Ephemeroptera of South America, Pensoft, Moscow.

Dosskey M.G., Vidon P., Gurwick N.P., Allan C.J., Duval T.P., Lowrance R., Michael G., Vidon P., Gurwick N.P., Allan C.J., Duval T.P. and Lowrance R., 2010. The role of riparian vegetation in protecting and improving chemical water quality in streams 1. J. Am. Water Resour. As., 47, 261-277.

Heino J., 2013. Does dispersal ability affect the relative importance of environmental control and spatial structuring of littoral macroinvertebrate communities? Oecologia, 171, 971-980.

Holzman R., Collar D.C., Mehta R.S. and Wainwright P.C., 2011. Functional complexity can mitigate performance trade-offs. Amer. Nat., 177, 69-83.

INMET, 2013. Instituto Nacional de Meteorologia, Brasil. Electronic database Publishing PhysicsWeb http//www.inmet. gov.br/portal/ accessed online 4 August 2013.

Jackson D.A., 1993. Stopping rules in principal components analysis: a comparison of heuristical and statistical approaches. Ecology, 74, 2204-2214.
Karr J.R., 1981. Assessment of biotic integrity using fish communities. Fisheries, 6, 21-27.

Karr J.R., 1999. Defining and measuring river health. Freshw. Biol., 41, 221-234.

Klapproth J.C. and Johnson J.E., 2000. Understanding the Science Behind Riparian Forest Buffers: Effects on Water Quality, Virginia Cooperative Extension, Virginia.

Landeiro V.L., Hamada N., Godoy B.S. and Melo A.S., 2010. Effects of litter patch area on macroinvertebrate assemblage structure and leaf breakdown in Central Amazonian streams. Hydrobiologia, 649, 355-363.

Legendre P. and Legendre L., 2012. Numerical Ecology, Elsevier, Amsterdam.

Ligeiro R., Hughes R.M., Kaufmann P.R., Macedo D.R., Firmiano K.R., Ferreira W.R., Oliveira D., Melo A.S. and Callisto M., 2013. Defining quantitative stream disturbance gradients and the additive role of habitat variation to explain macroinvertebrate taxa richness. Ecol. Indic., 25, 45-57.

Monteiro-Júnior C.S., Couceiro S.R.M., Hamada N. and Juen L., 2013. Effect of vegetation removal for road building on richness and composition of Odonata communities in Amazonia, Brazil. Int. J. Odonatol., 16, 764-798.

Nessimian J.L., Venticinque E.M., Zuanon J., De Marco P., Gordo M., Fidelis L., Batista J.D. and Juen J., 2008. Land use, habitat integrity, and aquatic insect assemblages in Central Amazonian streams. Hydrobiologia, 614, 117-131.

Nessimian J.L., Venticinque E.M., Zuanon J., De Marco P., Gordo M., Fidelis L., Batista J.D. and Juen J., 2013. Uso do solo, integridade de hábitat e agrupamentos de insetos aquáticos em igarapés na Amazônia Central. In: Castro G. (ed.), Conservação da Biodiversidade em paisagens antropizadas do Brasil, UFPR, Curitiba, 343-371.

Peel M.C., Finlayson B.L. and Mcmahon T.A., 2007. Updated world map of the Koppen-Geiger climate classification. Hydrol. Earth Syst. Sci., 11, 1633-1644.

Pereira L.R., Cabette H.S.R. and Juen L., 2012. Trichoptera as bioindicators of habitat integrity in the Pindaíba river basin, Mato Grosso (Central Brazil). Ann. Limnol. - Int. J. Lim., 48, 295-302.

Peres-Neto P.R., Jackson D.A. and Somers K.M., 2003. Giving meaningful interpretation to ordination axes: assessing loading significance in principal component analysis. Ecology, 84, 2347-2363.

Polegatto C. and Froehlich C.G., 2003. Feeding strategies in Atalophlebiinae (Ephemeroptera: Leptophlebiidae), with considerations on scraping and filtering. Behaviour, 1, 55-61.

Poole G.C., 2002. Fluvial landscape ecology: addressing uniqueness within the river discontinuum. Freshw. Biol, 47, 641-660.

Popielarz P.A. and Neal Z.P., 2007. The niche as a theoretical tool. Ann. Rev. Soc., 33, 65-84.

Primack R.B. and Rodrigues E., 2001. Biologia da conservação, Planta, Lodrina.

Salles F.F., 2006. A Ordem Ephemeroptera no Brasil (Insecta): taxonomia e diversidade. PhD thesis, Federal University of Viçosa.

Salles F.F., Nascimento J.M.C., Massariol F.C., Angeli K.B. and Barcelos P.R.B., 2010. Primeiro levantamento da fauna de Ephemeroptera (Insecta) do Espírito Santo, Sudeste do Brasil. Biota. Neotrop., 10, 293-306. 
Savage H.M., 1987. Biogeographic classification of the Neotropical Leptophlebiidae (Ephemeroptera) based upon geological centers of ancestral origin and ecology. Stud. Neotrop. Fauna E, 22, 37-41.

Scrimgeour G.J., 1991. Life history and production of Deleatidium (Ephemeroptera: Leptophlebiidae) in an unstable New Zealand river Life history and production of Deleatidium (Ephemeroptera: Leptophlebiidae) in an unst. New Zeal. J. Mar. Fresh, 25, 93-99.

Selvakumar C., Sivaramakrishnan K.G., Janarthanan S., Arumugam M. and Arunachalam M., 2014. Impact of riparian land-use patterns on Ephemeroptera community structure in river basins of the southern Western Ghats, India. Knowl. Manag. Aquat. Ecosyst., 412, 1-11.

Shimano Y., Cabette H.S.R., Salles F.F. and Juen L., 2010. Composição e distribuição da fauna de Ephemeroptera (Insecta) em área de transição Cerrado-Amazônia, Brasil. Iheringia, Sér. Zool., 100, 301-308.

Shimano Y., Salles F.F., Faria L.R.R., Cabette H.S.R. and Nogueira D.S., 2012. Distribuição espacial das guildas tróficas e estruturação da comunidade de Ephemeroptera (Insecta) em córregos do Cerrado de Mato Grosso, Brasil. Iheringia, Sér. Zool., 102, 187-196.

Shimano Y., Juen L., Salles F.F., Nogueira D.S. and Cabette H.S.R., 2013a. Environmental and spatial processes determining Ephemeroptera (Insecta) structures in tropical streams. Ann. Limnol. - Int. J. Lim., 49, 31-41.

Shimano Y., Salles F.F. and Juen L., 2013b. Study of the mayfly order Ephemeroptera (Insecta) in Brazil: a scienciometric review. Rev. Bras. Entomol., 57, 359-364.

Silva D.P., De Marco P. and Resende D.C., 2010. Adult odonate abundance and community assemblage measures as indicators of stream ecological integrity: a case study. Ecol. Indic., 10, 744-752.

Silva-Pinto N., Juen L., Cabette H.S.R. and De Marco P. Jr. 2012. Fluctuating asymmetry and wing size of argia tinctipennis Selys (Zygoptera: Coenagrionidae) in relation to riparian forest preservation status. Neotrop. Entomol., 41, 178-185.

Souza H.M.S., Cabette H.S.R. and Juen L., 2011. Baetidae (Insecta, Ephemeroptera) em córregos do cerrado matogrossense sob diferentes níveis de preservação ambiental. Iheringia, Sér. Zool., 101, 181-190.

Strahler H.N., 1957. Quantitative analysis of watershed geomorphology. Trans. Am. Geophys. Union, 38, 913-920.

Suga C.M. and Tanaka M.O., 2013. Influence of a forest remnant on macroinvertebrate communities in a degraded tropical stream. Hydrobiologia, 703, 203-213.

Tate C.M. and Heiny J.S., 1995. The ordination of benthic invertebrate communities in the South Platte River Basin in relation to environmental factors. Freshwater Biol., 33, 439-154.

Thorp J.H., Thoms M.C. and Delong M.D., 2006. The riverine ecosystem synthesis: biocomplexity in river networks across space and time. River. Res. Appl., 147, 123-147.

Thorp J.H., Martin C. and Thoms M.D.D., 2008. The Riverine Ecosystem Synthesis: Cohesiveness. Toward Conceptual, Elsevier, Amsterdam.

Vannote R.L., Minshall G.W., Cummins K.W., Sedell J.R. and Cushing C.E., 1980. The River Continuum Concept. Can. J. Fish. Aquat. Sci., 37, 130-137.

Wahl C.M., Neils A. and Hooper D., 2013. Impacts of land use at the catchment scale constrain the habitat benefits of stream riparian buffers. Freshw. Biol., 58, 2310-2324.

Warfe D.M., Barmuta L.A. and Wotherspoon S., 2008. Quantifying habitat structure: surface convolution and living space for species in complex environments. Oikos, 117, 1764-1773.

Whittaker R.J., Araújo M.B., Jepson P., Ladle R.J. and Watson J.E.M.W., 2005. Conservation Biogeography: assessment and prospect. Divers. Distrib., 11, 3-23.

Xu M., Wang Z., Duan X. and Pan B., 2014. Effects of pollution on macroinvertebrates and water quality bio-assessment. Hydrobiol., 729, 247-259.

Yoshimura M., 2012. Effects of forest disturbances on aquatic insect assemblages. Entomol. Sci., 15, 145-154.

Zar J.H., 2010. Biostatistical Analysis, Pearson, London.

Zweig L.D. and Rabeni C.F., 2001. Biomonitoring for deposited sediment using benthic invertebrates: a test on 4 Missouri streams. J. N Am. Benthol. Soc., 20, 643-657. 